\title{
Absence of correlation between ex vivo susceptibility to doxycycline and pfteQ-pfmdt gene polymorphism in French Guiana
}

\author{
Marie Mura ${ }^{1,2}$, Sébastien Briolant ${ }^{1,2,3}$, Damien Donato ${ }^{1}$, Béatrice Volney ${ }^{1}$, Stéphane Pelleau ${ }^{1}$, Lise Musset ${ }^{1}$ \\ and Eric Legrand ${ }^{1,4^{*}}$
}

\begin{abstract}
Background: In French Guiana, doxycycline is used for both chemoprophylaxis and the treatment of malaria. The presence of isolates with reduced ex vivo susceptibility to doxycycline in French Guiana makes it critical to identify any genetic determinants contributing to the chemosusceptibility level of Plasmodium falciparum to doxycycline, such as pfmdt and pftetQ, which were recently identified as potential molecular markers in African isolates.

Methods: A Bayesian statistical approach was used to define different ex vivo doxycycline phenotypes. The pfmdt and pftetQ gene copy numbers were quantified by quantitative real-time polymerase chain reaction in 129 P. falciparum isolates collected between 2000 and 2010, and pftetQ, pfrps7, pfssurRNA, and pflsurRNA sequences were analysed after amplification by polymerase chain reaction.
\end{abstract}

Results: PftetQ and pfmdt copy numbers were not associated with reduced susceptibility to doxycycline in P. falciparum within French Guiana. Sequence analysis of the genes revealed five known single nucleotide polymorphisms. Three new SNPs were identified in the apicoplast ribosomal RNA long sub-unit (pflsurRNA): C740T, A1875C and A1875T. These polymorphisms were not associated with reduced chemosusceptibility to doxycycline.

Conclusions: The present study does not validate pfmdt and pftetQ genes as molecular markers of decreased susceptibility to doxycycline in P. falciparum isolates in French Guiana.

Keywords: Malaria, Doxycycline, Molecular markers, Anti-malarial drug resistance, French Guiana

\section{Background}

Malaria remains a public health problem in French Guiana despite measures to strengthen health protection and disease prevention. It occurs in geographical foci located along the rivers and near gold-mining sites in the Amazonian forest [1], where the high number of illegal foreign workers unfortunately limits the impact of preventive measures. Self-medication using imported molecules with an unclear compliance contributes to the selection of drug-resistant parasites in the region [2]. Plasmodium falciparum accounts for

\footnotetext{
*Correspondence: eric.legrand@pasteur.fr

${ }^{4}$ Present Address: Unité de Recherche Génétique et Génomique des Insectes Vecteurs, Institut Pasteur, 25-28 rue du Dr Roux, 75724 Paris Cedex 15, France

Full list of author information is available at the end of the article
}

$30 \%$ of the 1,000 malaria cases reported each year by the health regional agency [3]. As in the neighbouring countries of the Amazon basin, some strains of $P$. falciparum are resistant to chloroquine, amodiaquine, sulfadoxine-pyrimethamine, chloroquine-proguanil, halofantrine, and even quinine [4]. This justified the introduction of quinine-doxycycline combination therapy as a first-line treatment in 1995. It was replaced by the artemether-lumefantrine combination in 2002 but is still used to treat severe malaria in second-line treatment. Doxycycline is an antibiotic of the tetracycline family. Its anti-malarial activity has been known for 40 years following ex vivo [5, 6] and clinical studies [7-9]. The mode of action of this antibiotic on the Plasmodium parasite is not fully understood. In bacteria, cyclines inhibit protein synthesis by binding to 
protein S7 of the small ribosomal subunit and to various ribonucleic acids of the $16 \mathrm{~S}$ ribosomal RNA, preventing the binding of aminoacyl-transfer RNA to site A of the ribosome and thus blocking the elongation step of translation [10]. In P. falciparum, the doxycyline mechanism of action targets two organelles, the mitochondria and the apicoplast. Cyclines also decrease the activity of an enzyme, dihydroorotate dehydrogenase, involved in the de novo synthesis of pyrimidines [11]. A related drug, minocycline, is also thought to decrease the transcription of mitochondrial genes (sub-unit I of cytochrome $c$ oxidase and apocytochrome $b$ ) and plastid genes (sub-unit rpoB/C of RNA polymerase) [12]. Doxycycline appears to principally target the apicoplast in P. falciparum, and may block translation by binding to the small ribosomal sub-unit, causing a delayed death [13]. Doxycycline given on a daily basis has been shown to be an effective causal chemoprophylaxis [14]. It is now recommended by the French health authorities for chemoprophylaxis in countries with high prevalence of chloroquine resistance or multidrug resistance (group 3 countries), as in French Guiana [15]. French troops deployed in the illegal gold mines take $100 \mathrm{mg}$ daily doses of doxycycline for prophylaxis. The ability of $P$. falciparum to rapidly develop resistance and the use of doxycycline for both chemoprophylaxis and the treatment of malaria in French Guiana impose a close monitoring of resistance to this drug. No clinical treatment failure has been reported so far, but doxycycline is always used in combination for treatment. Although reported cases of malaria under doxycycline chemoprophylaxis are mostly believed to have resulted from poor compliance [16], they could also be explained by resistance. It is critical to identify early signs of resistance before resistant strains become prevalent and compromise the clinical and prophylactic utility of the molecule. Indeed, Briolant et al. [17] identify an association between the $P$. falciparum metabolite drug transporter (pfmdt; PFE0825w) and P. falciparum GTPase TetQ (pftetQ; PFL171c) gene copy numbers, the $p f t e t Q$ KYNNNN sequence polymorphism and a decreased ex vivo susceptibility to doxycycline in African $P$. falciparum isolates. The threshold of decreased susceptibility to doxycycline was established ex vivo at $35 \mu \mathrm{M}$ [18].

This study first aimed to determine the distribution and range of $50 \%$ inhibitory concentrations $\left(\mathrm{IC}_{50}\right)$ of doxycycline for $800 \mathrm{P}$. falciparum isolates assayed between 2000 and 2010 in French Guiana. In the second part, the association between the pftetQ, pfmdt copy numbers sequence polymorphisms of the $p f t e t Q$, pfssurRNA, pflssurRNA, pfrps 7 and with decreased susceptibility to doxycycline has been evaluated.

\section{Methods}

\section{Plasmodium falciparum isolates}

Between January 2000 and December 2010, 800 P. falciparum isolates were obtained from the different health centres of French Guiana and collected by the CNRCP (Centre National de Référence pour la Chimiosensibilité du Paludisme) hosted by the parasitology laboratory of the Institut Pasteur de la Guyane. Fifty per cent inhibitory concentration $\left(\mathrm{IC}_{50}\right)$ to doxycycline was determined using the ex vivo isotopic method described by Le Bras et al. [19]. DNA was extracted from blood samples by QIAamp ${ }^{\circledR}$ DNA Blood (Qiagen) according to the manufacturer's protocol.

\section{Distribution and range of $\mathrm{IC}_{50}$}

The statistical analysis was designed to answer the specific question of whether $P$. falciparum has a different profile of susceptibility to doxycycline. Parasite susceptibility is expressed as the $\mathrm{IC}_{50}$. As a heterogeneous population is observed, the data are assumed to come from a univariate Gaussian mixture with k components. Each observation is assumed to come from one of the $\mathrm{k} \mathrm{com-}$ ponents, and the label of the group from which each observation comes is unknown. The number of components, the means, variances and weights of the different components in the model are unknown, as well as the vector of allocations of the observations. The analysis was performed in two steps. First, reversible jump Monte Carlo Markov Chains (RJMCMC) samplers were used to choose a suitable number of $\mathrm{k}$ components. The RJMCMC sampler is described by Richardson et al. [20]. The only difference with the algorithm is that we implemented only birth and death moves, following Cappé et al's recommendations [21]. Once a relevant number of components had been chosen, standard Gibbs samplers were run to obtain estimates of the model parameters and classify the observations [22]. It is well known that these classical Markov Chain Monte Carlo techniques are not sufficient to cover all the parameter space; it can stay within a neighbourhood of a local mode and may fail to visit other important modes. In order to improve the exploration of the parameter space and thereby improve convergence, the RJMCMC and Gibbs samplers were embedded in a population-based algorithm. Because of the 'label-switching' problem caused by symmetry in the likelihood of the model parameters [23], the mixture components should be labelled before making inferences about the parameters. A classical ordering constraint was used, which is biologically relevant here. The algorithms were run for 50,000 burn-in iterations and 20,000 postburn-in iterations. These numbers are classically sufficient to obtain reliable results. Moreover, each algorithm was run three times to check that results between two 
different runs were similar and that there was no convergence problem. This analysis was performed with $R^{\circledR}$ software (version 2.10.1).

\section{Quantification of the pfmdt and pftetQ gene copy numbers} by TaqMan ${ }^{\circledR}$ real-time PCR

TaqMan ${ }^{\circledR}$ real-time polymerase chain reaction (PCR) was performed using ABI7300 (Applied Biosystems) to estimate the $p f m d t$ (PFE08254w) and $p f t e t Q$ (PFL1710c) gene copy numbers relative to the single-copy of pf $\beta$ tubulin gene (PF10_0084) in 129 isolates from the different phenotypic subpopulations.

Primers and probes were used as describe by Briolant et al. [17]. Individual PCR were performed using $1 \mathrm{X}$ TaqMan Universal PCR Master Mix (Applied Biosystems), $6 \mu \mathrm{M}$ forward and reverse primers, $4 \mu \mathrm{M}$ probe, and $1 \mu \mathrm{L}$ of template DNA in a final volume of $25 \mu \mathrm{L}$. The thermal cycling conditions were $50^{\circ} \mathrm{C}$ for $2 \mathrm{~min}, 95^{\circ} \mathrm{C}$ for $10 \mathrm{~min}$, then 50 cycles of $95^{\circ} \mathrm{C}$ for $15 \mathrm{~s}$ and $60^{\circ} \mathrm{C}$ for $1 \mathrm{~min}$ for $p f m d t$, and $55^{\circ} \mathrm{C}$ for $10 \mathrm{~s}$ followed by $60^{\circ} \mathrm{C}$ for $1 \mathrm{~min}$ for pftetQ. Each sample was assayed in triplicate and analysed with SDS software (version 1.3; Applied Biosystems). The PCR efficiencies of all primers pairs were evaluated using a dilution series of $P$. falciparum 3D7 genomic DNA. The $2_{\mathrm{T}}^{-\Delta \Delta \mathrm{C}}$ method of relative quantification, where $\mathrm{C}_{\mathrm{T}}$ indicates the threshold cycle, was used to estimate the copy numbers of pfmdt and pftetQ genes with the formula $\Delta \Delta \mathrm{CT}=\left(\mathrm{C}_{\mathrm{T}, p f m d t}-\mathrm{C}_{\mathrm{T}, p f \beta t u b u l i n}\right)_{\text {sample }}-\left(\mathrm{C}_{\mathrm{T}, p f m d t}-\mathrm{C}_{\mathrm{T}}\right.$, pf $\beta$ ubulin $)_{\text {calibrator }}$ [24]. Genomic DNA extracted from P. falciparum 3D7, which has a single copy of each gene, was used for calibration, whereas pfßtubulin served as the control housekeeping gene in all experiments. Data were analysed using Epi info ${ }^{\circledR}$ software (version 3.5.1). Differences in the $p f m d t$ and $p f t e t Q$ gene copy numbers between the phenotypic groups were tested using the Kruskal-Wallis test. Genotype proportions were compared using the Fisher exact test. Statistical significance was denoted by $\mathrm{p} \leq 0.05$.

\section{Gene sequence polymorphism analysis}

Four genes, pftetQ, pfssurRNA, pflsurRNA and pfrps7, were amplified by PCR with oligonucleotide primer pairs designed using Primer $3^{\circledR}$ software (version 0.4.0) (Table 1). As there was only a few isolates with an $\mathrm{IC}_{50}$ exceeding the threshold, it was initially chosen to sequence genes from only ten isolates with the highest $\mathrm{IC}_{50}$ [median $40.15 \mu \mathrm{M}(\min 29.82 \mu \mathrm{M} ; \max 77.84 \mu \mathrm{M})$ ] and ten isolates with low $\mathrm{IC}_{50}$ to doxycycline [median $4.83 \mu \mathrm{M}$ ( $\min 3.28$; $\max 6.05$ )]. The reaction mixture consisted of $10 \times$ mix PCR Gold buffer ${ }^{\circledR}, 200 \mu \mathrm{M}$ of dNTPs, variable concentration of $\mathrm{MgCl}_{2}$ (Table 1), $200 \mathrm{nM}$ of forward and reverse primers, $4 \mathrm{UI} / 100 \mu \mathrm{L}$ of Ampli Taq Gold DNA polymerase (Applied Biosystems) and
Table 1 Forward and reverse primers, hybridization temperature and $\mathrm{MgCL}_{2}$ concentration used for polymerase chain reaction and sequence analysis

\begin{tabular}{|c|c|c|}
\hline Gene & $\begin{array}{l}\text { Forward Primer } \\
\text { Reverse Primer }\end{array}$ & $\mathrm{Tm} ;\left[\mathrm{MgCl}_{2}\right]$ \\
\hline \multirow[t]{4}{*}{ PftetQ } & $\begin{array}{l}\text { 5'-ATGTTTAAAAGAGTTTACGTATATAAAAATTC } \\
\text { 5'-GAAATGTTCATAAGAAATTGGTATATTATT }\end{array}$ & $50^{\circ} \mathrm{C} ; 3 \mathrm{mM}$ \\
\hline & $\begin{array}{l}\text { 5'-TTGTATGATAAATCCTAAACCAGATA } \\
\text { 5'-TTCATCGTCCTTCTCACAAATTATAT }\end{array}$ & $50^{\circ} \mathrm{C} ; 3 \mathrm{mM}$ \\
\hline & $\begin{array}{l}\text { 5'-TCACGACAAATGTGCTAGATAC } \\
\text { 5'-ATCATCATTTGTGGTGGATATATACAT }\end{array}$ & $55^{\circ} \mathrm{C} ; 3 \mathrm{mM}$ \\
\hline & $\begin{array}{l}\text { 5'-TTAAATATTTCAGATAACCTGGATAAAGA } \\
\text { 5'-TTGGGATACACTTTATATATTAACACTTTT }\end{array}$ & $55^{\circ} \mathrm{C} ; 3 \mathrm{mM}$ \\
\hline \multirow[t]{2}{*}{ PfssurRNA } & $\begin{array}{l}\text { 5'-AAAGAATATCAAAGGCGAAAGC } \\
\text { 5'-ACCCTTATCAAGAGTATGTTTTAACC }\end{array}$ & $60^{\circ} \mathrm{C} ; 4 \mathrm{mM}$ \\
\hline & $\begin{array}{l}\text { 5'-CTACTAGGGTATCTAATCCTATTTGCTA } \\
\text { 5'-GATAGTAGTTCAATTCTACTTATTTCCAT }\end{array}$ & $60^{\circ} \mathrm{C} ; 2 \mathrm{mM}$ \\
\hline \multirow[t]{2}{*}{ PflsurRNA } & $\begin{array}{l}\text { 5'-TATAGACCCGAAATCAAATGATCTAATT } \\
\text { 5'-TTTGGACCGTTATAGATACAGCCG }\end{array}$ & $60^{\circ} \mathrm{C} ; 3 \mathrm{mM}$ \\
\hline & $\begin{array}{l}\text { 5'-ACATCTGCCCAGTGCTATTATGTTA } \\
\text { 5'-AGCTAATGGTGAGATTTGAACTCATAA }\end{array}$ & $60^{\circ} \mathrm{C} ; 3 \mathrm{mM}$ \\
\hline Pfrps7 & $\begin{array}{l}\text { 5'-TTTCCATGATCTACATGCCCTA } \\
\text { 5'-TTCTTTAGATTCAACTGGGGTTTT }\end{array}$ & $60^{\circ} \mathrm{C} ; 4 \mathrm{mM}$ \\
\hline
\end{tabular}

$2 \mu \mathrm{L}$ of DNA in a final volume of $50 \mu \mathrm{L}$. Thermal Mastercycler $^{\circledR}$ (Eppendorf) were programmed as follows: $94^{\circ} \mathrm{C}$ for 10 min then 35 cycles alternating $94^{\circ} \mathrm{C}$ for $30 \mathrm{~s}$, hybridization temperature (Table 1 ) for $30 \mathrm{~s}$ and $72^{\circ} \mathrm{C}$ for extension at $1 \mathrm{~min}$ per $1,000 \mathrm{bp}$, followed by a 15 -min final extension step at $72^{\circ} \mathrm{C}$. The reaction products were sequenced by Millegen ${ }^{\circledR}$ biotechnologies (Labège, France). Sequences were analysed using MEGA ${ }^{\circledR}$ software (version 5.05). Epi Info ${ }^{\circledR}$ software (version 3.5.1) was used to perform data analysis. Differences in DNA sequences (pfssurRNA, pflsurRNA, pfrps7, pftetQ) and in amino acid sequences [PfTetQ, PfRps7-itals-as before ? (No because is official nomenclature)] between the two groups were tested using the Kruskal-Wallis test.

\section{Results}

Distribution and range of $\mathrm{IC}_{50}$ in 800 isolates between 2000 and 2010

Three runs of RJMCMC algorithms were performed, generating three chains of interest. All of these chains gave similar results for the number of components. Table 2 describes the mean values for the estimated posterior probabilities of the number of components in these three runs. The posterior distribution favoured four components, as the probability of $k=4$ was the highest. Three runs of Gibbs sampler were performed and gave very similar results (Table 3). Figure 1 shows that the posterior Gaussian mixture fits quite well with the observed $\mathrm{IC}_{50}$ density. 
Table 2 Estimated posterior probabilities of the number of components obtained on three runs

\begin{tabular}{llllllllll}
\hline $\mathbf{k = 1}$ & $\mathbf{k}=\mathbf{2}$ & $\mathbf{k}=\mathbf{3}$ & $\mathbf{k}=\mathbf{4}$ & $\mathbf{k}=\mathbf{5}$ & $\mathbf{k}=\mathbf{6}$ & $\mathbf{k}=\mathbf{7}$ & $\mathbf{k = 8}$ & $\mathbf{k = 9}$ & $\mathbf{k}=\mathbf{1 0}$ \\
\hline 0.00 & 0.00 & 0.00 & 0.42 & 0.32 & 0.15 & 0.07 & 0.03 & 0.01 & 0.00 \\
\hline
\end{tabular}

\section{The pfmdt and pftet $Q$ gene copy numbers}

From 800 samples, 129 isolates were selected within the four phenotypic groups: 58 isolates $\left[\mathrm{IC}_{50}\right.$ median $4.09 \mu \mathrm{M}$ (min 0.7; $\max 11.1$ )] from group 1, 43 isolates $\left[\mathrm{IC}_{50}\right.$ median $\left.13.7 \mu \mathrm{M}(\min 11.2 ; \max 21.96)\right]$ from group 2 , 23 isolates $\left[\mathrm{IC}_{50}\right.$ median $\left.26.5 \mu \mathrm{M}(\min 22.2 ; \max 37)\right]$ from group 3 , and five isolates $\left[\mathrm{IC}_{50}\right.$ median $50.92 \mu \mathrm{M}$ (min 44.5; $\max 77.84$ )] from group 4 . Only seven isolates had two or more copies of the pftetQ gene, showing no association with the phenotypic groups (Fisher test, $\mathrm{p}>0.05)$. Among these isolates, five presented very low $\mathrm{IC}_{50}$ to doxycycline (group 1), and two presented high $\mathrm{IC}_{50}$ (group 3). Two copies of the $p f m d t$ gene were found in only one group 3 isolate, with an $\mathrm{IC}_{50}$ of $35.8 \mu \mathrm{M}$. No statistical association was observed between the presence of multiple copies of $p f m d t$ or $p f t e t Q$ genes and a higher $\mathrm{IC}_{50}$ or belonging to phenotypic group 3 or 4 .

Table 3 Parameters of the Gaussian mixture with four components for the three runs

\begin{tabular}{|c|c|c|c|c|}
\hline & run1 & run2 & run3 & Mean \\
\hline \multicolumn{5}{|l|}{$\mu$} \\
\hline$\mu 1$ & 7.46 & 7.44 & 7.42 & 7.44 \\
\hline$\mu 2$ & 13.89 & 13.76 & 13.77 & 13.81 \\
\hline$\mu 3$ & 24.12 & 23.69 & 23.77 & 23.86 \\
\hline$\mu 4$ & 54.49 & 53.94 & 53.98 & 54.14 \\
\hline \multicolumn{5}{|l|}{$\sigma$} \\
\hline$\sigma 1$ & 6.72 & 6.66 & 6.61 & 6.66 \\
\hline$\sigma 2$ & 16.00 & 15.95 & 15.97 & 15.97 \\
\hline$\sigma 3$ & 39.91 & 39.47 & 39.30 & 39.56 \\
\hline$\sigma 4$ & 158.50 & 161.31 & 162.94 & 160.92 \\
\hline \multicolumn{5}{|l|}{ W } \\
\hline w1 & 0.5439 & 0.5367 & 0.5358 & 0.5388 \\
\hline w2 & 0.3818 & 0.3816 & 0.3859 & 0.3831 \\
\hline w3 & 0.0633 & 0.0704 & 0.0672 & 0.0670 \\
\hline w4 & 0.0108 & 0.0112 & 0.0109 & 0.0110 \\
\hline \multicolumn{5}{|l|}{$\mathrm{n}$} \\
\hline $\mathrm{n} 1$ & 481 & 477 & 480 & 479 \\
\hline $\mathrm{n} 2$ & 281 & 285 & 282 & 283 \\
\hline n3 & 32 & 32 & 32 & 32 \\
\hline $\mathrm{n} 4$ & 6 & 6 & 6 & 6 \\
\hline$\beta$ & 46.06 & 45.89 & 45.80 & 45.9 \\
\hline
\end{tabular}

$\mu$ means, $\sigma$ standard deviation, $w$ weights of each components, $n$ number of observation for each components, $\beta \beta$ parameter.

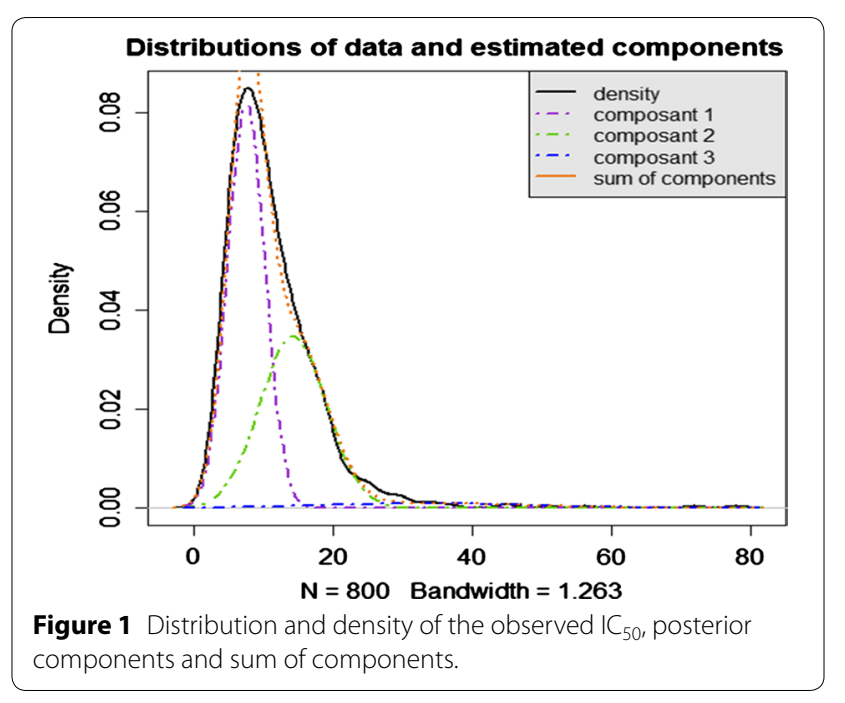

Gene sequence polymorphism

Sequence analysis of the four genes in ten isolates with high $\mathrm{IC}_{50}$ and 10 isolates with low $\mathrm{IC}_{50}$ revealed new single-nucleotide polymorphisms (SNPs) in the gene sequence of the long sub-unit ribosomal RNA (pflsur$R N A$ ), namely C740T (Genbank accession number: KM272854), A1875C (Genbank accession number: KM272855) and A1875T (Genbank accession number: KM272856). These SNPs were not previously noted in the PlasmoDB SNP database [25]. They were found in 35,20 and $30 \%$ of isolates, respectively. Other SNPs were observed in the $p f t e t Q$ and $p f s s u r R N A$ genes, but neither they nor PfTetQ KYNNNN sequence polymorphism were significantly associated with the doxycycline $\mathrm{IC}_{50}$ phenotypes. No mutation was observed in pfrps 7.

\section{Discussion}

Doxycycline belongs to the tetracycline family of antibiotics. Tetracyclines are an effective anti-malarial, but their mechanism of action is much less clearly defined for Plasmodium than for bacteria. Ex vivo, doxycycline specifically impaired the expression of apicoplast genes and blocked apicoplast genome replication, leading to the loss of apicoplast function in the progeny of treated parasites and delayed death [13]. Most prophylactic failures of doxycycline against $P$. falciparum are associated with poor compliance [26] or inadequate low doses [27]. Doxycycline pharmacokinetic parameters could explain some 
of these cases, given its short elimination half-life $(16 \mathrm{~h})$ for slow action and delayed anti-malarial effect [28]. The early detection of reduced susceptibility or resistance to doxycycline entailed the monitoring of chemosusceptibility. A Bayesian mixture modelling approach was adopted to study doxycyline susceptibility phenotypes in the isolates circulating in French Guiana. All $800 \mathrm{IC}_{50}$ values were classified into four components. All the isolates from group 4 and two isolates from group $3 \mathrm{had}$ an $\mathrm{IC}_{50}$ value above the decreased susceptibility threshold of $35 \mu \mathrm{M}$ [18]. This represents $1 \%$ of isolates. These data are consistent with clinical observations of limited prophylactic failures when doxycycline is used according to recommendations. Genotyping analysis was then necessary to try to identify the molecular basis of the susceptibility differences and correlate genetic profiles to the phenotypes.

Three potential molecular markers of decreased susceptibility were identified in African isolates, namely copy number variations of the $p f m d t$ and $p f t e t Q$ gene and PfTetQ KYNNNN sequence polymorphism [17]. These variations were also associated with decreased ex vivo susceptibility to doxycycline in isolates from the National Reference Centre for Imported Malaria in France mainland [29]. PfTetQ protein belongs to the translation elongation factor GTPase family, and possesses a plastid signal peptide [30]. It shares sequence similarity with several other bacterial resistance proteins [31]. Although the results showed find multiple copies of pftet $Q$ gene in seven isolates, five of these had a very low $\mathrm{IC}_{50}$. It therefore follows that this genetic determinant is not associated with a decreased susceptibility to doxycycline in French Guiana and cannot be used to monitor doxycycline susceptibility. The protein product of the pfmdt gene corresponds to a putative metabolic drug transporter of the plasma membrane, and shows a similar sequence to the tetracycline resistance protein PfTetA, an efflux pump involved in bacterial resistance [32]. It was hypothesized that variations in the copy number of $p f m d t$ gene can produce multiple efflux pumps and mediate resistance by increasing transport of doxycycline out of the cell. Previous research has demonstrated that an increased copy number of the P. falciparum multidrug resistant 1 (pfmdr1; PFE1150w) gene, which encodes an efflux pump of the vacuolar digestive membrane, is associated with mefloquine resistance in P. falciparum isolates from Southeast Asia [33]. Two copies of the $p f m d t$ gene were found in just one isolate, with an $\mathrm{IC}_{50}$ of $35.8 \mu \mathrm{M}$. The other nine isolates which $\mathrm{IC}_{50}$ values corresponded to a decreased doxycycline susceptibility did not present multiple copies of $p f m d t$. This gene could therefore be involved in decreased doxycycline susceptibility but cannot be the only factor involved. Finally, PfTetQ
KYNNNN sequence polymorphism was not associated with doxycycline $\mathrm{IC}_{50}$ phenotypes. A recent study on Kenyan isolates found a correlation between this polymorphism and a decreased susceptibility to doxycycline but not for $p f m d t$ and $p f t e t Q$ gene copy numbers. Surprisingly, multiple pftet $Q$ gene copy numbers were associated with very low $\mathrm{IC}_{50}$ [34]. Further studies in other endemic regions are needed to test the reliability of these molecular polymorphisms as markers for decreased doxycyline susceptibility.

In this study, the results did shown observe any mutation in the pfrps 7 and pfssurRNA genes, although $\mathrm{S} 7$ and the small sub-unit ribosomal RNA are molecular targets of tetracyclines in bacteria $[35,36]$. Three new SNPs were found in the DNA sequence of pflsurRNA, but without any association with a decreased susceptibility to doxycycline.

\section{Conclusions}

Doxycycline is currently the only anti-malarial drug for which no P. falciparum treatment failure has been documented. The distribution of ex vivo susceptibility to doxycycline in French Guiana divided the population in four phenotypic groups. Only $1 \%$ of the 800 tested isolates had reduced susceptibility to doxycycline ex vivo, consistent with clinical observations. The present study does not validate the $p f m d t$ and $p f t e t Q$ gene as molecular markers of decreased susceptibility to doxycycline in $P$. falciparum French Guiana isolates.

\section{Authors' contributions}

MM carried out the molecular genetic studies. BV, DD, LM, and EL carried out the ex vivo evaluation of doxycycline susceptibility. EL, and LM supervised, carried out and coordinated the field collections of patient isolates. SB and EL conceived and coordinated the study. MM and EL analysed the data. MM, SB, $S P, L M$, and EL drafted the manuscript. All authors read and approved the final manuscript.

\section{Author details}

1 Laboratoire de Parasitologie, Centre National de Référence du Paludisme aux Antilles, Guyane, Institut Pasteur de la Guyane, Cayenne Cedex, France. ${ }^{2}$ Direction Interarmées du Service de Santé en Guyane, Quartier La Madeleine, BP 6019, 97306 Cayenne Cedex, French Guiana. ${ }^{3}$ Institut de Recherche Biomédicale des Armées, BP 73, 91223 Brétigny sur Orge Cedex, France. ${ }^{4}$ Present Address: Unité de Recherche Génétique et Génomique des Insectes Vecteurs, Institut Pasteur, 25-28 rue du Dr Roux, 75724 Paris Cedex 15, France.

\section{Acknowledgements}

This study benefited from European commission grant REGPOT-CT-2011285837-STRonGer within the FP7 programme and the French Ministry of Health (InVS agency, Paris).

\section{Compliance with ethical guidelines}

\section{Competing interests}

The authors declare that they have no competing interests.

Received: 22 December 2014 Accepted: 1 July 2015

Published online: 25 July 2015 


\section{References}

1. Carme B, Ardillon V, Girod R, Grenier C, Joubert M, Djossou F et al (2009) Update on the epidemiology of malaria in French Guiana (in French). Med Trop (Mars) 69:19-25

2. Jambou R, Legrand E, Niang M, Khim N, Lim P, Volney B et al (2005) Resistance of Plasmodium falciparum field isolates to in vitro artemether and point mutations of the SERCA-type PfATPase6. Lancet 366:1960-1963

3. Musset L, Legrand E (2011) Activity report of National Reference Centre of Malaria Chemio-resistance (2011). Institut Pasteur ed. 2011

4. Legrand E, Volney B, Meynard JB, Mercereau-Puijalon O, Esterre P (2008) In vitro monitoring of Plasmodium falciparum drug resistance in French Guiana: a synopsis of continuous assessment from 1994 to 2005. Antimicrob Agents Chemother 52:288-298

5. Divo AA, Geary TG, Jensen JB (1985) Oxygen- and time-dependent effects of antibiotics and selected mitochondrial inhibitors on Plasmodium falciparum in culture. Antimicrob Agents Chemother 27:21-27

6. McColm AA, McHardy N (1984) Evaluation of a range of antimicrobial agents against the parasitic protozoa, Plasmodium falciparum, Babesia rodhaini and Theileria parva in vitro. Ann Trop Med Parasitol 78:345-354

7. Clyde DF, Miller RM, DuPont HL, Hornick RB (1971) Antimalarial effects of tetracyclines in man. J Trop Med Hyg 74:238-242

8. Rieckmann KH, Willerson D Jr, Carson PE (1971) Drug potentiation against pre-erythrocytic stages of Plasmodium falciparum. Trans R Soc Trop Med Hyg 65:533-535

9. Willerson D Jr, Rieckmann KH, Carson PE, Frischer H (1972) Effects of minocycline against chloroquine-resistant falciparum malaria. Am J Trop Med Hyg 21:857-862

10. Chopra I, Roberts M (2001) Tetracycline antibiotics: mode of action, applications, molecular biology, and epidemiology of bacterial resistance. Microbiol Mol Biol Rev 65:232-260 (second page, table of contents)

11. Prapunwattana P, O'Sullivan WJ, Yuthavong Y (1988) Depression of Plasmodium falciparum dihydroorotate dehydrogenase activity in in vitro culture by tetracycline. Mol Biochem Parasitol 27:119-124

12. Lin Q, Katakura K, Suzuki M (2002) Inhibition of mitochondrial and plastid activity of Plasmodium falciparum by minocycline. FEBS Lett 515:71-74

13. Dahl EL, Shock JL, Shenai BR, Gut J, DeRisi JL, Rosenthal PJ (2006) Tetracyclines specifically target the apicoplast of the malaria parasite Plasmodium falciparum. Antimicrob Agents Chemother 50:3124-3131

14. Andersen SL, Oloo AJ, Gordon DM, Ragama OB, Aleman GM, Berman JD et al (1998) Successful double-blinded, randomized, placebo-controlled field trial of azithromycin and doxycycline as prophylaxis for malaria in western Kenya. Clin Infect Dis 26:146-150

15. Debort T, Danis M (2008) Recommendations for clinical practice. Management and prevention of imported Plasmodium falciparum malaria (Revision 2007 of the 1999 consensus conference). Short text. Med Mal Infect 38:54-67

16. Ollivier L, Michel R, Carlotti MP, Mahe P, Romand O, Todesco A et al (2008) Chemoprophylaxis compliance in a French battalion after returning from malaria-endemic area. J Travel Med 15:355-357

17. Briolant S, Wurtz N, Zettor A, Rogier C, Pradines B (2010) Susceptibility of Plasmodium falciparum isolates to doxycycline is associated with pftetQ sequence polymorphisms and pftetQ and pfmdt copy numbers. J Infect Dis 201:153-159

18. Briolant S, Baragatti M, Parola P, Simon F, Tall A, Sokhna C et al (2009) Multinormal in vitro distribution model suitable for the distribution of Plasmodium falciparum chemosusceptibility to doxycycline. Antimicrob Agents Chemother 53:688-695

19. Le Bras J, Deloron P (1983) In vitro study of drug sensitivity of Plasmodium falciparum: evaluation of a new semi-micro test. Am J Trop Med Hyg 32:447-451

20. Richardson S, Green PJ (1997) On bayesian analysis of mixtures with an unknown number of components. J R Stat Soc Series B 59:731-792

21. Cappé O, Robert C, Ryden T (2003) Reversible jump, birth-and-death and more general continuous time Markov Carlo samplers. J R Stat Soc Series B 65:679-700

22. Diebolt J, Robert C (1994) Estimation of a finite mixture distributions through Bayesian sampling. J R Stat Soc Series B 56:363-375

23. Jarsa A, Holmes CC, Stephens DA (2005) Markov chain Monte Carlo methods and the label switching problem in Bayesian mixture modeling. Stat Science 20:50-67
24. Livak KJ, Schmittgen TD (2001) Analysis of relative gene expression data using real-time quantitative PCR and the 2(-Delta Delta C(T)) Method. Methods 25:402-408

25. Plasmodium data base (Plasmodb) (2014) www.plasmodb.org. Accessed 8 Dec 2014

26. Shanks GD, Edstein MD, Suriyamongkol V, Timsaad S, Webster HK (1992) Malaria chemoprophylaxis using proguanil/dapsone combinations on the Thai-Cambodian border. Am J Trop Med Hyg 46:643-648

27. Pang L, Limsomwong N, Singharaj P (1988) Prophylactic treatment of vivax and falciparum malaria with low-dose doxycycline. J Infect Dis 158:1124-1127

28. Shmuklarsky MJ, Boudreau EF, Pang LW, Smith II, Schneider I, Fleckenstein Let al (1994) Failure of doxycycline as a causal prophylactic agent against Plasmodium falciparum malaria in healthy nonimmune volunteers. Ann Intern Med 120:294-299

29. Gaillard T, Briolant S, Houzé S, Baragatti M, Wurtz N, Hubert V et al (2013) Pftet $Q$ and pfmdt copy numbers as predictive molecular markers of decreased ex vivo doxycycline susceptibility in imported Plasmodium falciparum malaria. Malar J 12:414

30. Zuegge J, Ralph S, Schmuker M, McFadden GI, Schneider G (2001) Deciphering apicoplast targeting signals-feature extraction from nuclearencoded precursors of Plasmodium falciparum apicoplast proteins. Gene 280:19-26

31. Briolant S, Almeras L, Fusai T, Rogier C, Pradines B (2007) Cyclines and malaria (in French). Med Trop (Mars) 67:86-96

32. Roberts MC (2005) Update on acquired tetracycline resistance genes. FEMS Microbiol Lett 245:195-203

33. Price RN, Uhlemann AC, Brockman A, McGready R, Ashley E, Phaipun L et al (2004) Mefloquine resistance in Plasmodium falciparum and increased pfmdr1 gene copy number. Lancet 364:438-447

34. Achieng AO, Ingasia LA, Juma DW, Cheruiyot AC, Okudo CA, Yeda RA et al (2014) Reduced in vitro doxycycline susceptibility in Plasmodium falciparum field isolates from Kenya is associated with PfTetQ KYNNNN sequence polymorphism. Antimicrob Agents Chemother 58:5894-5899

35. Pioletti M, Schlunzen F, Harms J, Zarivach R, Gluhmann M, Avila H et al (2001) Crystal structures of complexes of the small ribosomal subunit with tetracycline, edeine and IF3. EMBO J 20:1829-1839

36. Sidhu AB, Sun Q, Nkrumah LJ, Dunne MW, Sacchettini JC, Fidock DA (2007) In vitro efficacy, resistance selection, and structural modeling studies implicate the malarial parasite apicoplast as the target of azithromycin. J Biol Chem 282:2494-2504

\section{Submit your next manuscript to BioMed Central and take full advantage of:}

- Convenient online submission

- Thorough peer review

- No space constraints or color figure charges

- Immediate publication on acceptance

- Inclusion in PubMed, CAS, Scopus and Google Scholar

- Research which is freely available for redistribution 